\title{
Decreased pH does not alter metamorphosis but compromises juvenile calcification of the tube worm Hydroides elegans
}

\author{
Ackley C. Lane $\cdot$ Joy Mukherjee $\cdot$ Vera B. S. Chan • \\ Vengatesen Thiyagarajan
}

Received: 9 January 2012/ Accepted: 23 August 2012/Published online: 11 September 2012

(C) The Author(s) 2012. This article is published with open access at Springerlink.com

\begin{abstract}
Using $\mathrm{CO}_{2}$ perturbation experiments, we examined the pre- and post-settlement growth responses of a dominant biofouling tubeworm (Hydroides elegans) to a range of $\mathrm{pH}$. In three different experiments, embryos were reared to, or past, metamorphosis in seawater equilibrated to $\mathrm{CO}_{2}$ values of about 480 (control), 980, 1,480, and $2,300 \mu$ atm resulting in $\mathrm{pH}$ values of around 8.1 (control), 7.9, 7.7, and 7.5, respectively. These three decreased $\mathrm{pH}$ conditions did not affect either embryo or larval development, but both larval calcification at the time of metamorphosis and early juvenile growth were adversely affected. During the 24-h settlement assay experiment, half of the metamorphosed larvae were unable to calcify tubes at $\mathrm{pH} 7.9$ while almost no tubes were calcified at $\mathrm{pH}$ 7.7. Decreased ability to calcify at decreased $\mathrm{pH}$ may indicate that these calcifying tubeworms may be one of the highly threatened species in the future ocean.
\end{abstract}

\section{Introduction}

Carbon dioxide $\left(\mathrm{CO}_{2}\right)$ produced by anthropogenic activity is absorbed by the ocean, reducing the seawater $\mathrm{pH}$ and carbonate chemistry that can adversely affect marine organisms, especially calcifiers, many of which are ecological keystones and/or economically important (Widdicombe and Spicer 2008; Doney et al. 2009; Byrne 2011).

Communicated by S. Dupont.

A. C. Lane · J. Mukherjee · V. B. S. Chan .

V. Thiyagarajan $(\square)$

The Swire Institute of Marine Science and School of Biological

Sciences, The University of Hong Kong, Pok Fu Lam,

Hong Kong SAR

e-mail: rajan@hku.hk
Given the variable and species-specific responses to low $\mathrm{pH}$, it is important to examine the responses of representative species from as many phyla as possible, especially regarding calcifying organisms (Harley et al. 2006; Ries et al. 2009), for example, the fast growing species that constitute sessile biofouling communities such as barnacles and tubeworms. The majority of sessile marine invertebrates have pelagic larvae specialized for dispersal and the colonization of new habitats. However, planktonic larvae are largely dependent on the pelagic environment to provide the appropriate conditions for growth, that is, any given environmental parameter (e.g., temperature, salinity, $\mathrm{pH}$, and food availability) can turn stressful if conditions are outside larval tolerance ranges (Qiu and Qian 1997). Despite the costs inherent in planktonic life, the necessity of dispersal is more important (Pechenik 1999). After a potentially stressful period of development (from minutes to days), larvae enter a competent stage wherein their primary objective is to attach to a substratum and metamorphose into the juvenile form (Hadfield 2000). The metamorphic process is the pinnacle of the larval phase and as such depends on, and can be affected by, the larval experience up until that point (Thiyagarajan 2010).

Larval attachment, metamorphosis, and subsequent juvenile development of sessile marine invertebrates are dynamic and complicated processes involving the recognition of environmental chemical and physical cues, intensive tissue remodeling, and rapid calcification to form protective shells (Rittschof et al. 1998; Steinberg et al. 2002; Nedved and Hadfield 2009). The vulnerability of larval stages and processes to environmental stressors may extend to $\mathrm{pH}$, possibly being more vulnerable to $\mathrm{pH}$ changes than their adult counterparts (Kurihara 2008; Dupont and Thorndyke 2009; Talmage and Gobler 2010; Byrne 2011). The highly complicated process of larval metamorphosis 
has often been targeted as the weakest link for antifouling compounds and technologies (Rittschof et al. 2011).

Larval life stages differ in more ways than just their degree of exposure to stressors; oftentimes, different life stages have different calcification strategies, for example, the non-calcifying larvae of corals or tube worms, or the primarily chitinous larvae of barnacles that later produce calcareous shell. The larvae of the coral Porites astreoides, for example, were unaffected while juvenile growth rates decreased with decreasing $\mathrm{pH}$ (Albright et al. 2008). Similarly, the barnacle Balanus amphitrite showed only a small decrease in early juvenile shell strength when raised from hatching in decreased $\mathrm{pH}$ conditions (McDonald et al. 2009), and while another study observed small decreases in metamorphosis in the same species at the most extreme $\mathrm{pH}$ (7.3) (Wong et al. 2011), the effects of decreased $\mathrm{pH}$ in barnacles are most obvious during the adult phase, especially when exposed to decreased $\mathrm{pH}$ for a longer time, for example, reduced growth, survival, and brood quality of the early juveniles and adults of the temperate (intertidal) barnacle species, Semibalanus balanoides (Findlay et al. 2010). The contrast between the larval and juvenile/adult response to decreased $\mathrm{pH}$ in corals and (likely) barnacles may be explained by different calcification strategies; coral larvae do not calcify while adults produce aragonite skeletons, and barnacle larvae construct highly chitinous exoskeletons while the juvenile/adult form produces a thick calcitic external shell (Luquet and Marin 2004).In contrast, three copepod species showed high tolerance to decreased $\mathrm{pH}$ throughout larval development, into their adult life and even into multiple generations (Mayor et al. 2007; Kurihara and Ishimatsu 2008). Furthermore, molluscan larvae often suffer deleterious effects, having trouble calcifying their aragonitic larval shells, with some species even unable to calcify at all when in decreased $\mathrm{pH}$ conditions (e.g., unshelled abalone, Byrne et al. (2011).

Similarly, the biphasic life history of Hydroides elegans (Annelida, Polychaeta, Canalipalpata Serpulidae; Haswell, 1883) displays a distinct difference in calcification between larval and adult forms (Nedved and Hadfield 2009). The $H$. elegans is a common biofouling tubeworm used as a model in developmental and biofouling research, which has tolerances to low salinity ( $\sim 20 \mathrm{ppt}$ ), large temperature ranges $\left(15-30{ }^{\circ} \mathrm{C}\right.$ ), and ranges of food concentrations (developing to settlement with as little as $10^{4}$ cells ml $^{-1}$ ) (Qiu and Qian 1997), The only hard structures produced during larval development are the small, chitinous, setae, whereas the adult produces a large calcareous tube that contains both calcitic and aragonitic forms of calcium carbonate (Tanur et al. 2010; Chan et al. 2012). The aim of this study was to examine the effects of $\mathrm{pH}$ on the early life history stages of a tube building polychaete worm, especially interesting considering the contrasting calcification strategies of the pelagic and sessile stages. Expanding on the differences in calcification strategies and associated energetic efforts, the larval phase was expected to be largely unaffected by decreased $\mathrm{pH}$ (and decreased carbonate saturation), while the calcifying adult phase was expected to find calcification, and therefore growth, more difficult. Contrary to the evidence supporting this hypothesis, the only other study examining the effects of decreased $\mathrm{pH}$ (and copper pollution) on the larvae of a tube-dwelling polychaete (Pomatoceros lamarckii) has shown that low $\mathrm{pH}$ (7.6 and 7.4) adversely affected larval survival (Lewis et al. 2012). The only other tube-dwelling polychaete observed under low $\mathrm{pH}$ conditions (Spirobis marioni) was not found at the lower $\mathrm{pH}$ stations along a natural $\mathrm{pH}$ gradient; however, whether the larvae settled and juveniles could not grow, whether the larvae chose not to settle in low $\mathrm{pH}$ areas, or whether the larvae were unable to tolerate, the lower $\mathrm{pH}$ is unknown (Cigliano et al. 2010). Here, the H. elegans embryos were reared in seawater manipulated by bubbling $\mathrm{CO}_{2}$-enriched air to study the larval development, metamorphosis, and juvenile growth in response to $\mathrm{pH}$. Performance was tracked from embryo to 9 days postmetamorphosis in a range of $\mathrm{pH}$ environments measuring larval survival, growth, metamorphosis, and juvenile tube length as indicators of physiological condition and overall fitness. Successful attachment and metamorphosis of larvae on suitable substratum and the subsequent rapid juvenile development are important determinants of initiation, establishment, and persistence of marine communities (Qian et al. 2000), and studies such as this contribute greatly to the predictions of future ocean ecologies and biofouling potential of this species.

\section{Methods}

Study organism, spawning, and larval culture

Adult Hydroides elegans were collected from floats on a fish farm in Hong Kong $\left(22^{\circ} 19^{\prime} \mathrm{N}, 114^{\circ} 16^{\prime} \mathrm{E}\right)$ on June 1 , 2011 (Experiment 1), June 11, 2011 (Experiment 2), and August 9, 2011 (Experiment 3). Adults were conditioned in the laboratory until used ( $<7$ days). Adults were placed in Petri dishes with $0.22-\mu \mathrm{m}$ filtered seawater (FSW) with $34 \mathrm{ppt}$ salinity and spawning was induced by breaking the tube at room temperature $\left(\sim 24{ }^{\circ} \mathrm{C}\right)$. Gametes from about 25 females and 10 males were collected for each experiment. Fertilization is successful at a broad range of sperm concentrations of greater than $1 \times 10^{5}$ sperm ml$^{-1}(>90 \%$ success), so all eggs were combined with small amounts of sperm from each male (approximate sperm concentration greater than $1 \times 10^{5}$ sperm ml $^{-1}$ ) (Pechenik et al. 2007). After $1 \mathrm{~h}$, embryos were concentrated and cleaned using 
20- $\mu \mathrm{m}$ mesh and FSW and the total number of eggs was estimated by taking $100 \mu \mathrm{l}$ aliquots of the homogenous egg mixture. Fertilized eggs were then distributed into the culture tanks described in the experimental designs below. The culture tanks, excepting the differences in $\mathrm{pH}$ treatments, were all maintained at $26{ }^{\circ} \mathrm{C}$; salinity was not manipulated but constant at 32-33 ppt; and cultures were fed using concentrated cultures of Isochryis galbana resulting in the concentrations of approximately 50,000 cells $\mathrm{ml}^{-1}$. This concentration of food is optimal for larval and juvenile growth (Qiu and Qian 1997) and was chosen to maximize larval health, despite the potential for reducing the magnitude of any observed effect.

Experimental design: $\mathrm{pH}$, ocean acidification, and carbonate system

Seawater partial pressure of carbon dioxide $\left(p \mathrm{CO}_{2}\right)$ was raised by bubbling $\mathrm{CO}_{2}$-enriched air into the tanks at rates sufficient to achieve the desired $\mathrm{pH}$ and carbonate system using the "European Project on Ocean Acidification" (EPOCA) standard procedures (Riebesell et al. 2010). Two to four $\mathrm{pH}$ (or $p \mathrm{CO}_{2}$ ) treatments, depending on the experiment, were used in this study. Three or four replicate culture tanks were assigned to each $\mathrm{pH}$ treatment, covering OA scenarios representing current $p \mathrm{CO}_{2}$ levels (seawater $\mathrm{pH} \approx 8.1$ ) and a range of levels expected to occur over the next 250 years: $\mathrm{pH} 7.9$, pH 7.7, and pH 7.5 (Caldeira and Wickett 2003). The required treatment $\mathrm{pH}$ levels were achieved by adjusting the flow rate of air and $\mathrm{CO}_{2}$ using dual (air and $\mathrm{CO}_{2}$ ) variable area flow meter/controllers (ColeParmer Inc.). The $\mathrm{pH}$ was measured twice daily throughout the culture period using a Mettler-Toledo $\mathrm{pH}$ meter (NBS scale). Food availability, dissolved oxygen, temperature, and salinity were measured daily. Once in 2 days, total alkalinity was measured using the Apollo SciTech's AC-A2 Alkalinity Titrator and compared to seawater reference materials (Batch 98, A.G. Dickson, Scripps Institution of Oceanography). The carbonate chemistry equilibrium of each tank was calculated using the CO2SYS program (Pierrot et al. 2006).

Experiment 1: Effect of $\mathrm{pH}$ on embryo and larval development

This experiment was designed to test the effect of $\mathrm{pH}$ on embryo and larval development. There were two treatments, pH 8.1 (control) and pH 7.6. Embryos were added into culture tanks with final concentrations of 10 eggs per milliliter. Embryonic developmental success was assessed after $16 \mathrm{~h}$ when $50 \%$ of the embryos in the control $\mathrm{pH}$ hatched into the trochophore larval stage. After $16 \mathrm{~h}$, undeveloped embryos were removed and hatched larvae were placed in the same treatment cultures containing FSW with algal food (Isochrysis galbana). Algal suspensions were maintained at approximate concentrations of 50,000 cells $\mathrm{ml}^{-1}$ (Qiu and Qian 1997).

During embryo and larval culture period, the following two measurements were taken. (1) To examine embryo development, the undeveloped embryos and the newly hatched trochophore larvae were filtered out of the tanks after $16 \mathrm{~h}$ and concentrated into $100 \mathrm{ml}$, and from these three, subsamples of $100 \mu \mathrm{l}$ were taken after mixing the beaker to ensure a homogenous distribution of embryos and larvae. The swimming larvae were then counted in each of the samples and compared to the number of eggs originally added to assess percent embryonic developmental success. (2) Larval size and survivorship measurements were taken when the majority of larvae attained competency to attach and metamorphosis (after $\sim 96 \mathrm{~h}$ ). Larval size was measured on a compound microscope (Leica DFC 280) with micrometer. Larval survivorship was determined by the percentage of larvae that had achieved competence after $96 \mathrm{~h}$, or the time when approximately $80 \%$ of larvae in the control were competent. Larval competency was judged using their ability to metamorphose on natural biofilms and/or their behavior, that is, at the time of competence larvae generally swim slowly and start crawling close to surface (Qian 1999).

\section{Experiment 2: Effect of $\mathrm{pH}$ on larval metamorphosis}

This experiment was designed to study the effects of $\mathrm{pH}$ on larval metamorphosis with or without tube using three $\mathrm{pH}$ treatments: $\mathrm{pH}$ 8.1, 7.9, and 7.7. Lower $\mathrm{pH}$ was not included in this experiment because the majority of larvae did not metamorphose with tube in the $\mathrm{pH} 7.6$ treatment of Experiment 1. Embryos were cultured to the competent stage (in $\sim 96 \mathrm{~h}$ ) as described in Experiment 1. Each of the three $\mathrm{pH}$ treatments consisted of four replicate cultures and six replicate assay dishes per culture, each bioassay dish contained about 20-25 competent larvae. Larvae were placed in polystyrene Petri dishes (Falcon no. 1006) with $10 \mathrm{ml}$ of FSW with corresponding $\mathrm{pH}$ levels. Bioassay dishes with larvae were kept in incubation chambers that were supplied with $\mathrm{CO}_{2}$-enriched air at the same levels as the treatment cultures for $\mathrm{pH}$ control. In each dish, there was a biofilmed (7-day-old assemblage of natural microbial community) coverslip to trigger larval metamorphosis and to serve as suitable hard substrate for larvae (Harder et al. 2002). Larvae were allowed to metamorphose on these biofilmed-coverslips for $24 \mathrm{~h}$. During the bioassay, the $\mathrm{pH}$ generally decreased $0.2-0.3$ units, irrespective of treatment conditions, likely due to larval calcification, respiration, and the microbial community (biofilm) used to induce larval metamorphosis. After $24 \mathrm{~h}$, the number of individuals that were swimming, the number that were attached (metamorphosed without tube), and the number that had 
attached and had begun calcifying a tube were counted (metamorphosed with visible $\mathrm{CaCO}_{3}$ tube).

Experiment 3: Effect of $\mathrm{pH}$ on post-settlement (juvenile) growth

This experiment was designed to examine the effects of $\mathrm{pH}$ ranging from 8.1 (control) to 7.5 on the growth rate of successfully metamorphosed and calcifying individuals. Since the majority of larvae in Experiment 2 failed to produce $\mathrm{CaCO}_{3}$ tubes at the time of metamorphosis at $\mathrm{pH} 7.7$, here larvae were forced to metamorphose on a clean glass surface through mechanical stimulation (passing them through 300 micron mesh) and by keeping them at high density (e.g., 20 larval per $\mathrm{ml}$ ) on a clean glass surface. Additionally, the $\mathrm{pH}$ during this longer $(36 \mathrm{~h})$ attachment and metamorphosis period was allowed to increase in the treatments $(<0.3 \mathrm{pH}$ unit increase). This method triggered the competent larvae to metamorphose and begin calcification, and $>10$ individuals were obtained per replicate culture tank to examine their post-settlement growth performance at different $\mathrm{pH}$ levels. These newly metamorphosed larvae were reared for 9 days in different $\mathrm{pH}$ seawater using Isochrysis galbana as their sole food source in culture conditions similar to the larvae. Juvenile growth rate was measured using the tube length as proxy after 1.5, 3, and 9 days. Lengths were measured by taking photos of $>10$ juveniles and measuring them using Image $\mathbf{J}$ photo analysis software. For each treatment, there were four replicate culture tanks, and for each tank, at least 10 individuals were measured.

Data analysis

All data were tested for normality and homogeneity of variance with Shapiro-Wilk's test and Cochran's C-test, respectively. After meeting the assumptions of parametric analysis, embryonic and larval development data were analyzed using one-way ANOVA and repeated measure ANOVA (for all developmental stages). The slopes of the fitted linear regressions of juvenile growth rates were compared using an ANCOVA designed for comparing multiple slopes (Zar 1999). Since larval metamorphosis data did not meet parametric analysis assumptions even after data transformation, it was analyzed using nonparametric Kruskal-Wallis test.

\section{Results}

Carbonate chemistry variability due to $\mathrm{pH}$ treatment

Mean $( \pm \mathrm{SD})$ values of the carbonate system in $\mathrm{pH}$ treatments are shown in Table 1. Treatment conditions were

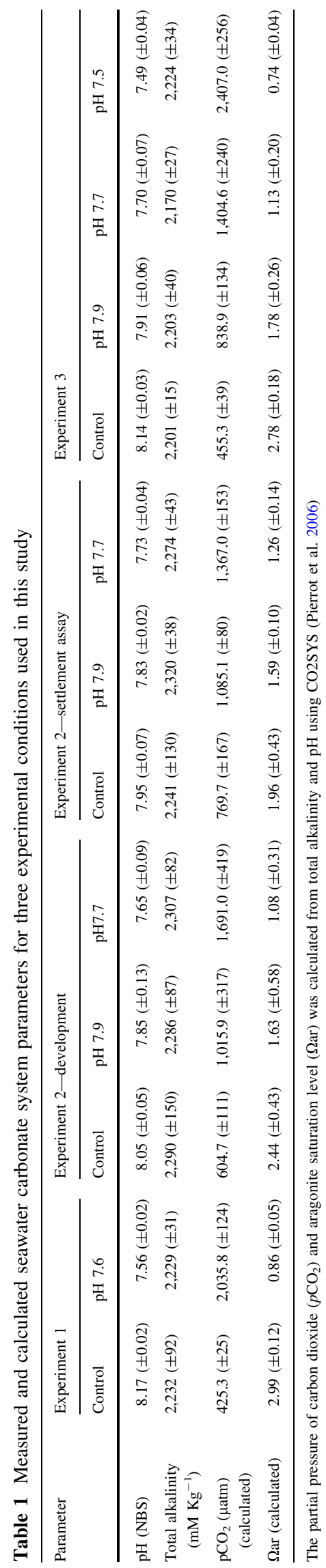


reliably stable within replicates (no effect of replicates, $F<0.5, \quad p>0.5$ for all within treatment ANOVAs, Table 1), but treatment conditions did slightly change over time and among experiments possibly due to changes in $\mathrm{CO}_{2}$ pressure or changes in ambient levels of atmospheric $\mathrm{CO}_{2}$ during the experimental period. Nevertheless, the total alkalinity (TA) was approximately constant, ranging from 2,200 to $2,300 \mu \mathrm{mol} 1^{-1}$, irrespective of $\mathrm{pH}$ levels and experiments. Also, the treatment levels of $p \mathrm{CO}_{2}$ were close to the values used to calculate the target $\mathrm{pH}$ using theoretical values; control $p \mathrm{CO}_{2}=\sim 430-600 \mu \mathrm{atm}, \mathrm{pH}$ 7.9, $p \mathrm{CO}_{2}=$ ambient $+380-415 \mu \mathrm{atm}, \mathrm{pH} 7.7 p \mathrm{CO}_{2}=$ ambient $+950-1,100 \mu \mathrm{atm}$, and $\mathrm{pH} 7.5 \mathrm{pCO}_{2}=$ ambient + $1,947 \mu \mathrm{atm}$. These treatments are lower than yearly averages, with the lowest $\mathrm{pH}$ treatment going beyond seasonal fluctuations experienced by natural populations, which prefer the eastern oceanic waters of Hong Kong (mean $\mathrm{pH}$ 8.25, low $\mathrm{pH}$ 7.85) (Yung et al. 2001). $\mathrm{CaCO}_{3}$ mineral forms, calcite and aragonite, were saturated in all $\mathrm{pH}$ treatments with the exception of the $\mathrm{pH} 7.5$ treatment in Experiment 3 that had the average aragonite saturation of $\Omega$ ar $=0.76$ (undersaturated, Table 1).

\section{Embryonic and larval development (Experiment 1)}

About 50-60\% of embryos developed and hatched into trochophore larva within $16 \mathrm{~h}$, regardless of $\mathrm{pH}$ treatment. There was no significant difference in embryonic development success between the treatment and the control (ANOVA, $F=0.83, p>0.05$ ). Although the mean larval survivorship was about $20 \%$ at the end of the culture period, there was no significant difference between the treatment and the control (ANOVA, $F=2.93, p>0.05$ ), and the same was true when all the data were analyzed with a repeated measure ANOVA $(F=2.03, p>0.05)$ (Fig. 1).

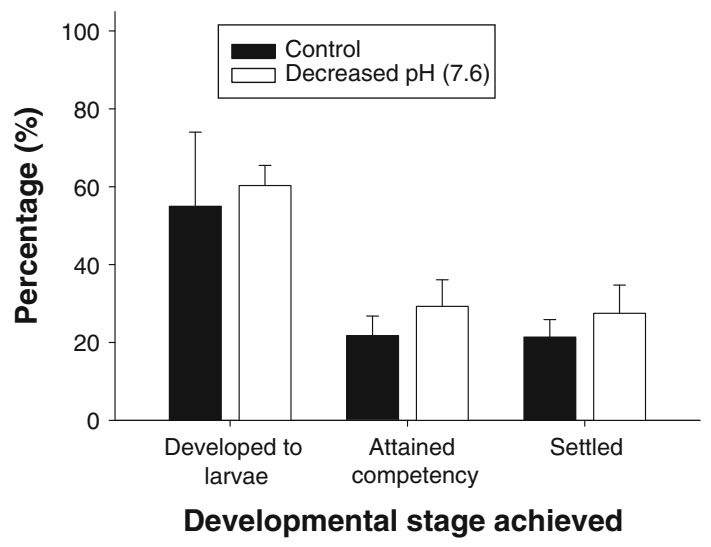

Fig. 1 Effect of $\mathrm{pH}$ on the development of the tubeworm (Hydroides elegans): percentage of embryos reaching the larval stage, the competent stage, and settling after exposure to control or decreased $\mathrm{pH}$ treatment $(\mathrm{pH} 7.6)$
Similarly, at the time of competence (to attach and metamorphose), larval total length (size) ranged between 247 and $278 \mu \mathrm{m}$ and there was no significant difference between the treatment and the control (ANOVA, $F=1.91$, $p>0.05)$.

Larval metamorphosis (Experiment 2)

The multi-species natural biofilm on glass induced $\sim 80 \%$ of larvae to attach and metamorphose with a $\mathrm{CaCO}_{3}$ tube within $24 \mathrm{~h}$ at the ambient $\mathrm{pH}$ level of 8.1 (control). Low $\mathrm{pH}$ treatments had no significant effect on percent larval metamorphosis (Kruskal-Wallis, $F=8.31, \quad p>0.05$; Fig. 2). However, there was a significant effect of $\mathrm{pH}$ on the percentage (or proportion) of larvae that did or did not produce $\mathrm{CaCO}_{3}$ tube after metamorphosis (Kruskal-Wallis test results: $\mathrm{H}_{\text {withtube }}=7.497 ; \quad \mathrm{H}_{\text {without }}$ tube $=5.692$; $p<0.01$; Fig. 2). Less than $30 \%$ of larvae produced $\mathrm{CaCO}_{3}$ tube after metamorphosis at pH 7.9 (Fig. 2, middle bar), and almost none of the metamorphosed larvae produced $\mathrm{CaCO}_{3}$ tube in the $\mathrm{pH} 7.7$ treatment.

\section{Early juvenile growth (Experiment 3)}

Once metamorphosed, the post-settlement growth of $\mathrm{CaCO}_{3}$ tube length increased from $\sim 0.5 \mathrm{~mm}$ on Day 1 (24 $\mathrm{h}$ after attachment) to $\sim 4.5 \mathrm{~mm}$ on Day 9 in the ambient (control) pH 8.1 (Fig. 3). Low pH had strong and significant negative effects on post-settlement growth rate (ANCOVA: $F=59.01, p<0.001$, Fig. 3 ). The multiple comparison tests showed three distinct juvenile groups on Day 9: the control $\mathrm{pH} 8.1(\sim 4.5 \mathrm{~mm}), \mathrm{pH} 7.9$ and 7.7 ( $3 \mathrm{~mm})$, and $\mathrm{pH} 7.5(\sim 1 \mathrm{~mm})$ (Fig. 3). The best fit trend line $\left(R^{2}=0.874\right)$ illustrates the differences (and

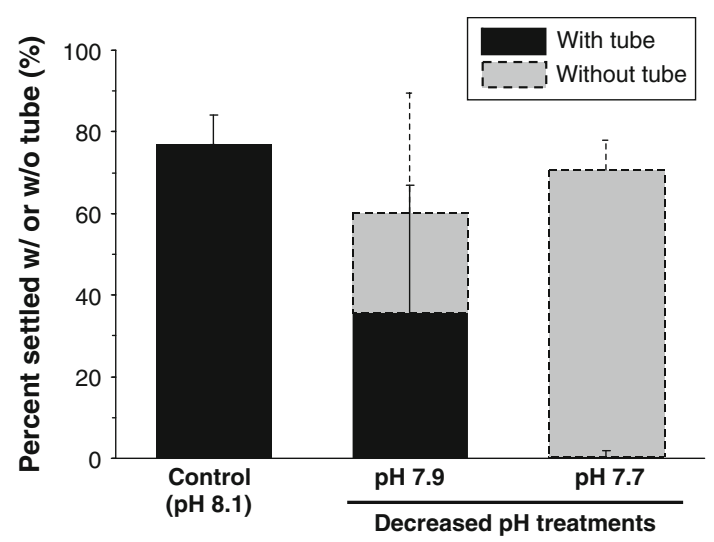

Fig. 2 Effect of $\mathrm{pH}$ on larval settlement (or attachment) and metamorphosis in the tubeworm (Hydroides elegans): percentage of larvae reaching settlement with or without visible $\mathrm{CaCO}_{3}$ tube 


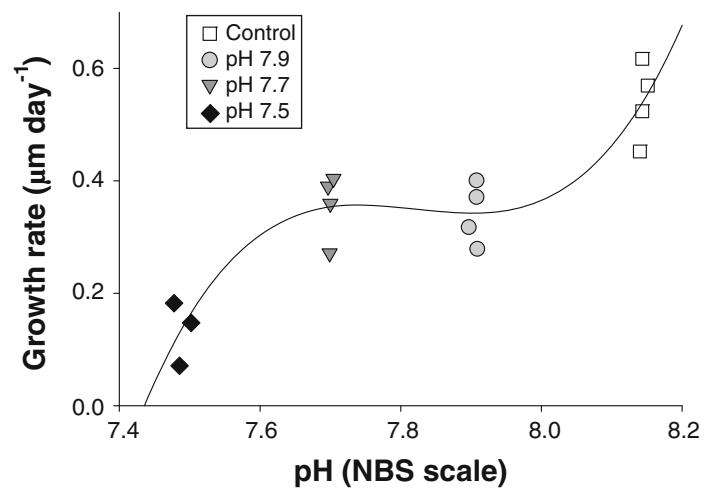

Fig. 3 Effect of $\mathrm{pH}$ on post-settlement growth rate of the $\mathrm{CaCO}_{3}$ tube in the tubeworm (Hydroides elegans). Each symbol represents the average of 10 to 25 randomly selected individuals from one replicate. There were 3 to 4 replicates per $\mathrm{pH}$ treatment

similarities) between groups, only $\mathrm{pH} 7.5$ experienced aragonite undersaturation (Fig. 3).

\section{Discussion}

In recent years, the impact of ocean acidification on larval growth and calcification has been the focus of many research projects (e.g., Kurihara 2008; Dupont and Thorndyke 2009; Dupont et al. 2010; O'Donnell et al. 2010; Talmage and Gobler 2010; Byrne 2011; Gazeau et al. 2011). However, the impact of this emerging stressor on the larval metamorphosis of economically important biofouling species has been elusive (McDonald et al. 2009) and thereby precludes our ability to predict or understand biofouling intensity in future ocean conditions (Poloczanska and Butler 2010). This study clearly demonstrates that metamorphosing larvae of the tubeworm, Hydroides elegans, suffer greatly at $\mathrm{pH}$ levels projected to occur in the coming century ( $\mathrm{pH}$ 7.7). Even if metamorphosis is successful (with tube), subsequent calcification and tube growth were significantly decreased in the low $\mathrm{pH}$ treatments projected to occur within this century $(\mathrm{pH}$ 7.9). Gregarious tube building polychaete worms create a unique habitat that houses many other marine invertebrates, and so the decrease in tube length will lead to decreased availability of heterogeneous hard substrates created by them, potentially leading to a restructuring of communities that depend on these ecosystem engineers (Poloczanska and Butler 2010). Thus, within this century, this ecologically (i.e., pioneering ecosystem engineer) and economically (i.e., biofouling) important species will be greatly threatened due to OA. Long-term consequences of impaired larval metamorphosis and early growth on population structure and dynamics are not yet known, but the reduced ability of postlarvae to calcify and decreased juvenile growth indicates that this species will be under severe stress in the coming century.

Larval development in low $\mathrm{pH}$ seawater (or in high- $\mathrm{CO}_{2}$ coastal oceans)

The "soft" trochophore larval stage of the tubeworm does not have structures that are dependent on calcification such as a $\mathrm{CaCO}_{3}$ shell or carapace and may not need to increase efforts to calcify as carbonate ion concentrations decrease. Therefore, they may be expected to suffer less detriment due to low $\mathrm{pH}$ environments than their calcifying counterparts in the phylums Mollusca and Echinodermata, that is, $>75 \%$ larvae did not develop at $\mathrm{pH}$ lower than 7.6 (Kurihara et al. 2007; Dupont et al. 2008; Clark et al. 2009; Miller et al. 2009; O'Donnell et al. 2009; Parker et al. 2009; Talmage and Gobler 2009; Watson et al. 2009; Byrne 2011). This hypothesis is supported by this study because larval development, growth, and survival were not significantly affected by low $\mathrm{pH}$. Fertilized eggs exposed to control and low $\mathrm{pH}$ conditions developed and settled with no significant differences (Fig. 1).The sensitivity of "soft" larval stages (including their embryos) to low $\mathrm{pH}$ is highly species-specific (Byrne 2011; Byrne et al. 2011), but most of the examined species, like this tubeworm, showed high relative tolerance to low $\mathrm{pH}$ during their pelagic developmental period. For example, similar to the non-effect seen in our experiments and contrary to calcifying larvae, $>75 \%$ of embryo and larvae of several cnidarian species successfully developed in $\mathrm{pH}$ as low as 7.3 (Kurihara 2008; Suwa et al. 2010). However, the non-calcifying nature of the $H$. elegans larvae may not explain the apparent tolerance to low $\mathrm{pH}$. Lecithotrophic life histories, like those of the cnidarians mentioned above, may be more robust to environmental stressors than their planktotrophic counterparts (Dupont et al. 2010); while this may be due to decreased environmental interaction, it is possible that the tolerance observed in this polychaete may be explained by some other, unmeasured parameter (e.g., increased metabolism or feeding rates). Additionally, the larvae of another tube worm Pomatoceros lamarckii suffered greatly at decreased $\mathrm{pH}$ ( $\mathrm{pH} 7.6$ and 7.4) (Lewis et al. 2012). The resilience of the pelagic larval stages of $H$. elegans to low $\mathrm{pH}$ may also be related to a preadapted ability to survive in a variety of unstable and unfavorable environments (Whiteley 2011). This tubeworm is found worldwide in oceanic and estuarine habitats, experiencing a wide range of environments with fluctuating $\mathrm{pH}$ 's, salinities, and temperatures (Qiu and Qian 1997), indicating that they may have been preselected to cope with stressors like low salinity, high temperature, and possibly low $\mathrm{pH}$.

Although larval morphological features appeared to be unaffected by low $\mathrm{pH}$ over their developmental stages, 
physiological processes are expected to be, and are, affected by low $\mathrm{pH}$ in several invertebrates (Widdicombe and Spicer 2008; Dupont and Thorndyke 2009). Such altered physiological fitness traits may contribute to decreased fitness or reduced energy reserves potentially observable in performance parameters other than survival and growth (Gaylord et al. 2011) such as altered metabolism (Michaelidis et al. 2005; Nakamura et al. 2011; Stumpp et al. 2011b) and reduced energy reserves (Talmage and Gobler 2010). Therefore, it is recommended that future studies should examine these physiological traits along with larval development to gain further new insights into $\mathrm{pH}$ effects on larval energetic balance (Clark et al. 2009; Nakamura et al. 2011).

\section{Larval metamorphosis in low $\mathrm{pH}$ seawater}

One of the main aims of this study was to determine how the tubeworm larval metamorphosis is exercised in a range of $\mathrm{pH}$ conditions. The majority of competent larvae, $>75 \%$, successfully attached and metamorphosed at $\mathrm{pH}$ levels as low as 7.6 (Figs. 1, 2). Larval attachment and subsequent metamorphosis, up to branchial lobe formation, in $H$. elegans do not require extensive gene translation or production of new tissues or organs (Carpizo-Ituarte and Hadfield 1998; Nedved and Hadfield 2009). This may contribute to why the attachment and initial metamorphosis can be predicted to be less sensitive to low $\mathrm{pH}$. Surprisingly, however, at an environmentally and climatically realistic $\mathrm{pH}$ level of 7.7 , almost none of those metamorphosed individuals produced a $\mathrm{CaCO}_{3}$ tube during the 24-h settlement assay. The reasons for this inability to build a visible $\mathrm{CaCO}_{3}$ tube at the time of metamorphosis in low $\mathrm{pH}$ conditions cannot be determined from our study, but may be related to (1) altered physiological mechanisms such as metabolism may result in decreased ability to calcify at decreased pH (Metzger et al. 2007; Ellis et al. 2009), (2) the exposure to decreased $\mathrm{pH}$ stress during their pelagic development might also have decreased their physiological fitness at the time of metamorphosis, due to the latent, or carryover, effects (Marshall et al. 2003; Dupont et al. 2012), and (3) unfavorable carbonate chemistry conditions to build tube at the site of metamorphosis, for example, lowered carbonate ion concentrations and/or $\mathrm{CaCO}_{3}$ mineral saturation states make calcification difficult. Latent effects can manifest in a variety of ways potentially resulting in impaired calcification-related signaling pathways, due to changes in gene and/or protein expression (Tomanek et al. 2011). Recent studies suggest that the response of calcification-specific genes to $\mathrm{pH}$ is highly species-specific, that is, down-regulated in larval sea urchin of the Lytechinus pictus (O'Donnell et al. 2010), the Strongylocentrotus purpuratus (Stumpp et al. 2011a), and up-regulated in the larval sea urchin Paracentrotus lividus (Martin et al. 2011). Nevertheless, molecular mechanisms underlying decreased $\mathrm{pH}$ impacts on calcification and/or other associated physiological processes are still a black box (Hofmann et al. 2008; Tomanek et al. 2011).

The discussion on possible sources of the inability to calcify can be expanded upon further when the third experiment to measure juvenile growth in decreased $\mathrm{pH}$ conditions is considered. In the Experiment 3, the stimulation by use of violent rinsing, overcrowding, brief $\mathrm{pH}$ relief or the 36-h period (as opposed to $24 \mathrm{~h}$ ) allowed for settlement enabled the larvae to calcify, despite the decreased $\mathrm{pH}$ of the treatments in which the larvae were reared. Future experiments will need proper controls to determine the exact inducer of the calcification, but assuming mechanical stimulation, overcrowding, and/or $\mathrm{pH}$ relief did induce the construction a $\mathrm{CaCO}_{3}$ tube, we are lead to the possibility that the inability to calcify normally is not caused by the calcification process being physically incapable of calcifying in decreased concentrations of carbonate ions. Secondly, the latent effects of development in decreased $\mathrm{pH}$ seawater may be reversible to some degree. The inducers may have inspired an increased metabolic effort, or potentially brought about a stress response that is not expressed when $\mathrm{pH}$ is the only stressor. The ability to quickly induce calcification would indicate that $\mathrm{pH}$ stress may be combated with a preexisting response that is not elicited by $\mathrm{pH}$ stress alone. Our experiment, however, does not account for the possibility that the different batches of larvae respond differently to $\mathrm{pH}$ stress.

Post-settlement growth in low $\mathrm{pH}$ seawater

Low $\mathrm{pH}$ conditions also dramatically retarded the postsettlement growth of $\mathrm{CaCO}_{3}$ tubes (Fig. 3); for instance, the mean tube growth in the low $\mathrm{pH} 7.5$ treatment was less than one-third that of the control. The tubeworm $\mathrm{H}$. elegans, like several other serpulid polychaetes, calcifies a bimineralic tube that contains comparable proportions of the two most common polymorphs of calcium carbonate, aragonite and calcite (Chan et al. 2012). The proportion of calcite to aragonite is highly variable in tubeworms, for example, $H$. norvegicus, $98_{\mathrm{Cal}}: 2_{\mathrm{Ar}} ; H$. dianthus, $60_{\mathrm{Cal}}: 40_{\mathrm{Ar}}$ (Tanur et al. 2010; Taylor et al. 2010). However, tubes of the newly metamorphosed $H$. elegans are dominated by the more soluble aragonite (Chan et al. 2012). Undersaturated levels of aragonite, in the $\mathrm{pH} 7.5$ treatment, during early juvenile growth may therefore suppress the calcification by promoting dissolution of the aragonitic tube or making the initial formation of aragonite more difficult. Additionally, because the acquisition of the individuals in this experiment may have selected for relatively strong genotypes, for example, those able and ready to metamorphose 
immediately and under stressful conditions, the measurements here may underestimate the effects of low $\mathrm{pH}$ on growth. Nevertheless, the poor calcification and subsequent depressed growth of calcified structures observed here are common symptoms of low $\mathrm{pH}$ conditions as previously observed (Findlay et al. 2009; Talmage and Gobler 2010). Likewise, a similar study encompassing the larval and juvenile period of a barnacle (McDonald et al. 2009) observed decreased juvenile shell strength, a similar finding as the larval stages were unaffected while juvenile calcification was altered in both H. elegans and Balanus amphitrite.

Tube length in H. elegans is related to its fitness, as it reflects individual size, and hence, reproductive output; smaller individuals produce fewer and low-quality gametes (Qiu and Qian 1997). Not only will these smaller individuals produce fewer offspring because of their size, but the $\mathrm{pH}$ stress that lead to the smaller size, if persistent, can be expected to place continued pressure on these animals and reduce reproductive output further than would be expected solely based on their smaller size. Decreases in reproductive output could result in reduced larval supply, potentially shrinking population sizes. Furthermore, aggregations of $H$. elegans can form large masses of highly diverse solid substrate, transforming what would otherwise be a relatively uninhabitable two-dimensional surface into a topographically diverse habitat that provides shelter for many animals and hugely increases the biofouling intensity (or biomass). Smaller animals with shorter tubes may lead to reductions in aggregation biomass and stability which in turn will affect the communities that utilize these aggregations, which prefer the three-dimensional structures of the aggregations to the otherwise smooth surfaces which H. elegans commonly colonize.

\section{Calcification strategies and their role in low $\mathrm{pH}$ tolerance}

Larvae of sessile calcifying invertebrates are exposed to the pelagic environment and therefore dependent on the environmental conditions for survival, leading to the "vulnerable larvae" theory (Pechenik 1999). The adult forms, on the other hand, have protective shells into which they may withdraw during stressful periods, potentially managing stress levels through physiological and/or behavioral changes. However, when considering a persistent stress like low $\mathrm{pH}$, exposure is permanent and differences in an organisms' physiological requirements may preempt the benefits of energetically expensive shells. For example, while non-calcifying coral larvae were not affected by low pH, adult calcification decreased (Albright et al. 2008; Suwa et al. 2010). While decalcification in adult corals may not be lethal (Fine and Tchernov 2007), it is clear that the other life stages may respond differently to decreased $\mathrm{pH}$. Calcifiers that are highly dependent on their calcified structures may require a large energy investment, so it has been hypothesized that these obligatory calcifiers will invest more energy in calcification to compensate, thereby reducing energy available for growth and reproduction (Melzner et al. 2011; Stumpp et al. 2011b). Like corals, other calcifiers have different life history stages with different calcification strategies (e.g., barnacles, tubeworms, and bryozoans), but few studies compare these life stages. For example, the only effect of low $\mathrm{pH}(\mathrm{pH}$ 7.4) on the barnacle Balanus amphitrite was observed in shell strength of juveniles, larvae developed, and metamorphosed normally (McDonald et al. 2009). Likewise, the observations of the tubeworm H. elegans, presented here, showed that larvae appeared tolerant while juvenile calcification was reduced. Contrarily, copepods, which use a similar calcification method to barnacles but do not produce large calcitic shells, performed well throughout their entire life cycle (Mayor et al. 2007; Kurihara and Ishimatsu 2008). However, a few studies provide evidence that calcification strategy is not the only determinant regarding $\mathrm{pH}$ tolerance, for example, lecithotrophic larvae and calcifying juveniles of the sea star Crossaster papposus increased growth in response to $\mathrm{pH}$ (Dupont et al. 2010), one coral's non-calcifying larvae (Acropora digitifera) experienced reduced metamorphosis at low pH (Nakamura et al. 2011), and more directly relevant to this research, Lewis et al. (2012) observed decreased larval survival in response to low $\mathrm{pH}$ despite the non-calcifying nature (Pomatoceros lamarckii). The potential importance of calcification strategy during larval stages complicates the "vulnerable larvae" hypothesis, while more vulnerable to many other stressors and predation, certain larval forms may be better suited for the future low $\mathrm{pH}$ conditions.

Long-term shifts toward stressful low $\mathrm{pH}$ environments

Predicting the long-term impact of decreased $\mathrm{pH}$ is not as simple as exposing extant animals to the pressures of future oceans, it must be considered that animals may adapt over coming centuries. While $H$. elegans clearly suffers detrimental effects at decreased $\mathrm{pH}$ levels expected to occur in the next 50-100 years, this species has the potential to go through multiple generations each year. A very conservative estimate would place at least 50 generations between now and the "future" high $\mathrm{CO}_{2}$ future tested in this study, a number well beyond what is necessary for natural selection (Carroll et al. 2007). The H. elegans is capable of living in coastal where $\mathrm{pH}$, salinity, and temperature are notoriously variable, and these periodically stressful conditions may play a role in maintaining genetic variability, variability that may now be selected from as environmental stressors 
like $\mathrm{pH}$ begin to shift in one direction (Hoffmann and Hercus 2000). Sunday et al. (2011) examined maternal and paternal influence on development in an urchin and a mussel, Pistevos et al. (2011) compared differences between colonies of a bryozoan, and Foo et al. (2012) observed significant environment by genetic interactions, all three studies found variable responses to $\mathrm{pH}$ (or temperature) between genetically related groups (clones or siblings) indicating some degree of heritable variation in $\mathrm{pH}$ response that may be selected for over the coming centuries. Adaptation over the coming century, especially in animals such as $H$. elegans with short generation times, should be expected and needs to be examined whether accurate forecasts of future ecosystems are to be made.

\section{Conclusions}

This study examined the effects of $\mathrm{pH}$ on larval development, attachment, and metamorphosis in a species whose phyla is greatly underrepresented in climate change and ocean acidification research to date. It is shown that the common biofouling tubeworm, $\mathrm{H}$. elegans, faces a great challenge when subjected to decreased $\mathrm{pH}$ conditions with symptoms like metamorphosing without a protective tube and decreased juvenile growth. As a major component of shallow subtidal fouling communities, reductions in their growth and biomass could lead to shifts in the composition, intensity, and function of the fouling community. Thus, our findings support the argument that "fouling communities, composed largely of calcifying organisms and organism with highly sensitive larval stages, will suffer decreases in biomass under acidified conditions or force shifts toward communities composed of non-calcifying, OA tolerant, species" (Poloczanska and Butler 2010). Other major calcifying biofoulers are also highly sensitive to decreased $\mathrm{pH}$, for example, mussels have shown decreased growth and reduced immune function (Michaelidis et al. 2005; Bibby et al. 2008) and barnacles are more likely to suffer as well as a consequence of delayed and smaller broods (Findlay et al. 2010); however, the changes elicited when only low $\mathrm{pH}$ is examined may be overcome when other conditions are met, such as when the mussel Mytilus edulis had sufficient food, the effects of low $\mathrm{pH}$ were reduced (Melzner et al. 2011). According to this study, fouling communities, especially those that are composed of the highly soluble form of $\mathrm{CaCO}_{3}$ (aragonite), for example, the tubeworm $H$. elegans, may be affected by the shifts in seawater carbonate chemistry system expected for the coming centuries due low $\mathrm{pH}$. However, without studies combining the effects of food supply and other stressors, it is impossible to truly predict how this species will respond. It is therefore important to biofouling research, in addition to ecologically focused OA research, to understand how biofouling community will be affected by decreased $\mathrm{pH}$ and what other factors may play a role in exacerbating or relieving those harmful effects.

Acknowledgments We thank PY Qian (HKUST, Hong Kong), A Ishimatsu (Nagasaki University, Japan), U Riebesell (EPOCA, Germany), and Gray Williams and Kenneth Leung (University of Hong Kong, Hong Kong) for their valuable discussions during the course of this project and for their support in setting up the ocean acidification facilities in our laboratory. Authors also thank Samuel Dupont and Hans-Otto Pörtner for the invitation, highly productive and constrictive editorial comments, and efforts to coordinate this special issue on ocean acidification. This study was supported by a seed (No. 201111159215) and SRT grants from The University Hong Kong, a research grant from the HKSAR-RGC (No. 778309 M) and the Area of Excellency project (No. AoE/P-04/2004).

Open Access This article is distributed under the terms of the Creative Commons Attribution License which permits any use, distribution, and reproduction in any medium, provided the original author(s) and the source are credited.

\section{References}

Albright R, Mason B, Langdon C (2008) Effect of aragonite saturation state on settlement and post-settlement growth of Porites astreoides larvae. Coral Reefs 27:485-490

Bibby R, Widdicombe S, Parry H, Spicer J, Pipe R (2008) Effect of ocean acidification on the immune response of the blue mussel, Mytilus edulis. Aquat Biol 2:67-74

Byrne M (2011) Impact of ocean warming and ocean acidification on marine invertebrate life history stages: vulnerabilities and potential for persistence in a changing ocean. Oceanogr Mar Biol Annu Rev 49:1-42

Byrne M, Ho M, Wong E, Soars NA, Selvakumaraswamy P, ShepardBrennand H, Dworjanyn SA, Davis AR (2011) Unshelled abalone and corrupted urchins: development of marine calcifiers in a changing ocean. Proc R Soc B 278:2376-2383

Caldeira K, Wickett ME (2003) Oceanography: anthropogenic carbon and ocean $\mathrm{pH}$. Nature 425:365

Carpizo-Ituarte E, Hadfield MG (1998) Stimulation of metamorphosis in the polychaete Hydroides elegans Haswell (Serpulidae). Biol Bull 194:14-24

Carroll S, Hendry A, Reznick D, Fox C (2007) Evolution on ecological time-scales. Funct Ecol 21:387-393

Chan VBS, Li C, Lane AC, Wang Y, Lu X, Shih K, Zhang T, Thiyagarajan $\mathrm{V}$ (2012) $\mathrm{CO}_{2}$-driven ocean acidification alters and weakens integrity of the calcareous tubes produced by the serpulid tubeworm, Hydroides elegans. PLoS ONE 7:e42718

Cigliano M, Gambi M, Rodolfo-Metalpa R, Patti F, Hall-Spencer J (2010) Effects of ocean acidification on invertebrate settlement at volcanic $\mathrm{CO}_{2}$ vents. Mar Biol 157:2489-2502

Clark D, Lamare M, Barker M (2009) Response of sea urchin pluteus larvae (Echinodermata: Echinoidea) to reduced seawater $\mathrm{pH}$ : a comparison among a tropical, temperate, and a polar species. Mar Biol 156:1125-1137

Doney SC, Fabry VJ, Feely RA, Kleypas JA (2009) Ocean acidification: the other $\mathrm{CO}_{2}$ problem. Annu Rev Mar Sci 1:169192

Dupont S, Thorndyke MC (2009) Impact of $\mathrm{CO}_{2}$-driven ocean acidification on invertebrates early life-history-what we know, 
what we need to know and what we can do. Biogeosci Discuss 6:3109-3131

Dupont S, Havenhand J, Thorndyke W, Peck L, Thorndyke M (2008) Near-future level of $\mathrm{CO}_{2}$-driven ocean acidification radically affects larval survival and development in the brittlestar Ophiothrix fragilis. Mar Ecol Prog Ser 373:285-294

Dupont S, Lundve B, Thorndyke M (2010) Near future ocean acidification increases growth rate of the lecithotrophic larvae and juveniles of the sea star Crossaster papposus. J Exp Zool B 314:382-389

Dupont S, Dorey N, Stumpp M, Melzner F, Thorndyke M (2012) Long-term and trans-life-cycle effects of exposure to ocean acidification in the green sea urchin Strongylocentrotus droebachiensis. Mar Biol. doi:10.1007/s00227-012-1921-х

Ellis RP, Bersey J, Rundle SD, Hall-Spencer JM, Spicer JI (2009) Subtle but significant effects of $\mathrm{CO}_{2}$ acidified seawater on embryos of the intertidal snail, Littorina obtusata. Aquat Biol 5:41-48

Findlay H, Wood H, Kendall M, Spicer J, Twitchett R, Widdicombe S (2009) Calcification, a physiological process to be considered in the context of the whole organism. Biogeosci Discuss 6:22672284

Findlay HS, Kendall MA, Spicer JI, Widdicombe S (2010) Relative influences of ocean acidification and temperature on intertidal barnacle post-larvae at the northern edge of their geographic distribution. Estuar Coast Shelf Sci 86:675-682

Fine M, Tchernov D (2007) Scleractinian coral species survive and recover from decalcification. Science 315:1811

Foo SA, Dworjanyn SA, Poore AGB, Byrne M (2012) Adaptive capacity of the habitat modifying sea urchin Centrostephanus rodgersii to ocean warming and ocean acidification: performance of early embryos. PLoS ONE 7:e42497. doi:10.1371/journal. pone. 0042497

Gaylord B, Hill TM, Sanford E, Lenz EA, Jacobs LA, Sato KN, Russell AD, Hettinger A (2011) Functional impacts of ocean acidification in an ecologically critical foundation species. J Exp Biol 214:2586-2594

Gazeau F, Gattuso JP, Greaves M, Elderfield H, Peene J, Heip CHR, Middelburg JJ (2011) Effect of carbonate chemistry alteration on the early embryonic development of the Pacific oyster (Crassostrea gigas). PLoS ONE 6:e23010

Hadfield MG (2000) Why and how marine-invertebrate larvae metamorphose so fast. Semin Cell Dev Biol 11:437-443

Harder T, Lam C, Qian PY (2002) Induction of larval settlement in the polychaete Hydroides elegans by marine biofilms: an investigation of monospecific diatom films as settlement cues. Mar Ecol Prog Ser 229:105-112

Harley CDG, Randall Hughes A, Hultgren KM, Miner BG, Sorte CJB, Thornber CS, Rodriguez LF, Tomanek L, Williams SL (2006) The impacts of climate change in coastal marine systems. Ecol Lett 9:228-241

Hoffmann AA, Hercus MJ (2000) Environmental stress as an evolutionary force. Bioscience 50:217-226

Hofmann GE, O'Donnell MJ, Todgham AE (2008) Using functional genomics to explore the effects of ocean acidification on calcifying marine organisms. Mar Ecol Prog Ser 373:219-225

Kurihara $\mathrm{H}$ (2008) Effects of $\mathrm{CO}_{2}$-driven ocean acidification on the early developmental stages of invertebrates. Mar Ecol Prog Ser 373:275-284

Kurihara H, Ishimatsu A (2008) Effects of high $\mathrm{CO}_{2}$ seawater on the copepod (Acartia tsuensis) through all life stages and subsequent generations. Mar Pollut Bull 56:1086-1090

Kurihara H, Kato S, Ishimatsu A (2007) Effects of increased seawater $p \mathrm{CO}_{2}$ on early development of the oyster Crassostrea gigas. Aquat Biol 1:91-98
Lewis C, Clemow K, Holt WV (2012) Early life-history responses of the serpulid polychaete Pomatoceros lamarckii (Quatrefages) to combined ocean acidification and metal exposures. Mar Biol (under review)

Luquet G, Marin F (2004) Biomineralisations in crustaceans: storage strategies. CR Palevol 3:515-534

Marshall DJ, Pechenik JA, Keough MJ (2003) Larval activity levels and delayed metamorphosis affect post-larval performance in the colonial ascidian Diplosoma listerianum. Mar Ecol Prog Ser 246:153-162

Martin S, Richier S, Pedrotti ML, Dupont S, Castejon C, Gerakis Y, Kerros ME, Oberhänsli F, Teyssié JL, Jeffree R (2011) Early development and molecular plasticity in the Mediterranean sea urchin Paracentrotus lividus exposed to $\mathrm{CO}_{2}$-driven acidification. J Exp Biol 214:1357-1368

Mayor D, Matthews C, Cook K, Zuur A, Hay S (2007) $\mathrm{CO}_{2}$-induced acidification affects hatching success in Calanus finmarchicus. Mar Ecol Prog Ser 350:91-97

McDonald M, McClintock J, Amsler C, Rittschof D, Angus R, Orihuela B, Lutostanski K (2009) Effects of ocean acidification over the life history of the barnacle Amphibalanus amphitrite. Mar Ecol Prog Ser 385:179-187

Melzner F, Stange P, Trübenbach K, Thomsen J, Casties I, Panknin U, Gorb SN, Gutowska MA (2011) Food supply and seawater $p \mathrm{CO}_{2}$ impact calcification and internal shell dissolution in the blue mussel Mytilus edulis. PLoS ONE 6:e24223

Metzger R, Sartoris FJ, Langenbuch M, Pörtner HO (2007) Influence of elevated $\mathrm{CO}_{2}$ concentrations on thermal tolerance of the edible crab Cancer pagurus. J Therm Biol 32:144-151

Michaelidis B, Ouzounis C, Paleras A, Pörtner H (2005) Effects of long-term moderate hypercapnia on acid-base balance and growth rate in marine mussels Mytilus galloprovincialis. Mar Ecol Prog Ser 293:109-118

Miller AW, Reynolds AC, Sobrino C, Riedel GF (2009) Shellfish face uncertain future in high $\mathrm{CO}_{2}$ world: influence of acidification on oyster larvae calcification and growth in estuaries. PLoS ONE 4:e5661

Nakamura M, Ohki S, Suzuki A, Sakai K (2011) Coral larvae under ocean acidification: survival, metabolism, and metamorphosis. PLoS ONE 6:e14521

Nedved BT, Hadfield MG (2009) Hydroides elegans (Annelida: Polychaeta): a model for biofouling research. In: Flemming H-C, Murthy PS, Venkatesan R, Cooksey K (eds) Marine and industrial biofouling. Springer, Berlin, pp 203-217

O'Donnell MJ, Hammond LTM, Hofmann GE (2009) Predicted impact of ocean acidification on a marine invertebrate: elevated $\mathrm{CO}_{2}$ alters response to thermal stress in sea urchin larvae. Mar Biol 156:439-446

O'Donnell MJ, Todgham AE, Sewell MA, Hammond LTM, Ruggiero K, Fangue NA, Zippay ML, Hofmann GE (2010) Ocean acidification alters skeletogenesis and gene expression in larval sea urchins. Mar Ecol Prog Ser 398:157-171

Parker L, Ross P, O'Connor W (2009) The effect of ocean acidification and temperature on the fertilization and embryonic development of the Sydney rock oyster Saccostrea glomerata (Gould 1850). Glob Change Biol 15:2123-2136

Pechenik JA (1999) On the advantages and disadvantages of larval stages in benthic marine invertebrate life cycles. Mar Ecol Prog Ser 177:269-297. doi:10.3354/meps 177269

Pechenik JA, Pearse JS, Qian PY (2007) Effects of salinity on spawning and early development of the tube-building polychaete Hydroides elegans in Hong Kong: not just the sperm's fault? Biol Bull 212:151-160

Pierrot D, Lewis E, Wallace DWR (2006) MS Excel Program Developed for $\mathrm{CO}_{2}$ System Calculations ORNL/CDIAC-105a. 
Carbon Dioxide Information Analysis Center, Oak Ridge National Laboratory, U.S. Department of Energy, Oak Ridge

Pistevos JCA, Calosi P, Widdicombe S, Bishop JDD (2011) Will variation among genetic individuals influence species responses to global climate change? Oikos 120:675-689

Poloczanska ES, Butler AJ (2010) Biofouling and climate change. In: Durr S, Thomason JC (eds) Biofouling. Blackwell Press, pp 333-347

Qian PY (1999) Larval settlement of polychaetes. Hydrobiologia 402:239-253

Qian P-Y, Rittschof D, Sreedhar B (2000) Macrofouling in unidirectional flow: miniature pipes as experimental models for studying the interaction of flow and surface characteristics on the attachment of barnacle, bryozoan and polychaete larvae. Mar Ecol Prog Ser 207:109-121

Qiu JW, Qian PY (1997) Combined effects of salinity, temperature and food on early development of the polychaete Hydroides elegans. Mar Ecol Prog Ser 152:79-88

Riebesell U, Fabry VJ, Hansson L, Gattuso JP (2010) Guide to best practices for ocean acidification research and data reporting. Publications Office of the European Union

Ries J, Cohen A, McCorkle D (2009) Marine calcifiers exhibit mixed responses to $\mathrm{CO}_{2}$-induced ocean acidification. Geology 37:11311134

Rittschof D, Forward RB, Cannon G, Welch JM, McClary M, Holm ER, Clare AS, Conova S, McKelvey LM, Bryan P, van Dover CL (1998) Cues and context: larval responses to physical and chemical cues. Biofouling 12:31-44

Rittschof D, Orihuela B, Harder T, Stafslien S, Chisholm B, Dickinson GH (2011) Compounds from silicones alter enzyme activity in curing barnacle glue and model enzymes. PLoS ONE 6:e16487

Steinberg PD, de Nys R, Kjelleberg S (2002) Chemical cues for surface colonization. J Chem Ecol 28:1935-1951. doi:10.1023/ a:1020789625989

Stumpp M, Dupont S, Thorndyke M, Melzner F (2011a) $\mathrm{CO}_{2}$ induced acidification impacts sea urchin larval development II: gene expression patterns in pluteus larvae. Comp Biochem Phys A 160:320-330

Stumpp M, Wren J, Melzner F, Thorndyke M, Dupont S (2011b) $\mathrm{CO}_{2}$ induced seawater acidification impacts sea urchin larval development I: elevated metabolic rates decrease scope for growth and induce developmental delay. Comp Biochem Phys A 160:331-340
Sunday JM, Crim RN, Harley CDG, Hart MW (2011) Quantifying rates of evolutionary adaptation in response to ocean acidification. PLoS ONE 6:e22881

Suwa R, Nakamura M, Morita M, Shimada K, Iguchi A, Sakai K, Suzuki A (2010) Effects of acidified seawater on early life stages of scleractinian corals (Genus Acropora). Fish Sci 76:93-99

Talmage SC, Gobler CJ (2009) The effects of elevated carbon dioxide concentrations on the metamorphosis, size, and survival of larval hard clams (Mercenaria mercenaria), bay scallops (Argopecten irradians), and Eastern oysters (Crassostrea virginica). Limnol Oceanogr 54:2072-2080

Talmage S, Gobler C (2010) Effects of past, present, and future ocean carbon dioxide concentrations on the growth and survival of larval shellfish. Proc Natl Acad Sci USA 107:17246-17251

Tanur AE, Gunari N, Sullan RMA, Kavanagh CJ, Walker GC (2010) Insights into the composition, morphology, and formation of the calcareous shell of the serpulid Hydroides dianthus. J Struct Biol 169:145-160

Taylor PD, Vinn O, Kudryavtsev A, Schopf JW (2010) Raman spectroscopic study of the mineral composition of cirratulid tubes (Annelida, Polychaeta). J Struct Biol 171:402-405

Thiyagarajan V (2010) A review on the role of chemical cues in habitat selection by barnacles: new insights from larval proteomics. J Exp Mar Biol Ecol 392:22-36

Tomanek L, Zuzow MJ, Ivanina AV, Beniash E, Sokolova IM (2011) Proteomic response to elevated $p \mathrm{CO}_{2}$ level in eastern oysters, Crassostrea virginica: evidence for oxidative stress. J Exp Biol 214:1836-1844

Watson SA, Southgate PC, Tyler PA, Peck LS (2009) Early larval development of the Sydney rock oyster Saccostrea glomerata under near-future predictions of $\mathrm{CO}_{2}$-driven ocean acidification. J Shellfish Res 28:431-437

Whiteley N (2011) Physiological and ecological responses of crustaceans to ocean acidification. Mar Ecol Prog Ser 430:257-271

Widdicombe S, Spicer JI (2008) Predicting the impact of ocean acidification on benthic biodiversity: what can animal physiology tell us? J Exp Mar Biol Ecol 366:187-197

Wong KKW, Lane AC, Leung PTY, Thiyagarajan V (2011) Response of larval barnacle proteome to $\mathrm{CO}_{2}$-driven seawater acidification. Comp Biochem Phys D 6:310-321

Yung YK, Wong CK, Yau K, Qian PY (2001) Long-term changes in water quality and phytoplankton characteristics in Port Shelter, Hong Kong, from 1988-1998. Mar Pollut Bull 42:981-992

Zar JH (1999) Biostatistical analysis. Prentice Hall, New Jersey 